\title{
A new species of Oiovelia from Colombia, with notes for other three species of South American Veliinae (Heteroptera: Gerromorpha: Veliidae)
}

\author{
Higor D.D. Rodrigues ${ }^{1}$ \& Luisa Fernanda Álvarez Arango ${ }^{2}$
}

1 Universidade Federal de Alagoas (UFAL), Museu de História Natural (MHN). Maceió, AL, Brasil. ORCID: http://orcid.org/0000-0002-9649-4142. E-mail: higorddr@gmail.com (corresponding author)

2 Universidad Católica de Oriente (UCO). Rionegro, Antioquia, Colômbia.

ORCID: http://orcid.org/0000-0001-9731-5962. E-mail: luisafernanda.alvarezarango@gmail.com

\begin{abstract}
The new species Oiovelia shepardi is described based on macropterous specimens from the departments of La Guajira and Antioquia in northwestern Colombia, and is compared to its presumed closest relative. The female of Paravelia cunhai Rodrigues \& Moreira, 2016 and the male of P. polhemusi Rodrigues, Moreira, Nieser, Chen \& Melo, 2014 are described for the first time. The specimens of the two species of Paravelia Breddin were collected in waters inside caves in the State of Pará, northern Brazil. Further, the micropterous form of Steinovelia vinnula (Drake, 1951) is described, compared with S. virgata (White, 1879), and new distributional records are provided. Illustrations and a geographic distribution map of all species treated here are presented.
\end{abstract}

Key-Words. Oiovelia; Paravelia; Steinovelia; New species; Taxonomy.

\section{INTRODUCTION}

The subfamily Veliinae (Veliidae) is represented in the American continents by seven genera: Altavelia Polhemus \& Moreira, 2019, Oiovelia Drake \& Maldonado-Capriles, 1952, Paravelia Breddin, 1898, Platyvelia Polhemus \& Polhemus, 1993, Steinovelia Polhemus \& Polhemus, 1993, Stridulivelia Hungerford, 1929, and Veloidea Gould, 1934 (Moreira, 2015; Polhemus et al., 2019). All species of these genera are endemic to the New World, except Paravelia taipiensis (Chessman, 1926), which is recorded from the eastern Pacific (Rodrigues et al., 2014b).

In the present paper, a new species of Oiovelia from Colombia, descriptions of the previously unknown sex of two species of Paravelia, and description of the micropterous form of Steinovelia vinnula (Drake, 1951) are presented. In addition, all species treated here are illustrated and their geographical records are presented in a distribution map.

\section{MATERIALS AND METHODS}

The material examined consists of dry-mounted preserved specimens deposited in the following institutions: Essig Museum of Entomology
Collection, Berkeley, California, United States (EMEC); Instituto Nacional de Pesquisas da Amazônia, Manaus, Brazil (INPA); Entomological Collection of the Museo Javeriano de Historia Natural Lorenzo Uribe S.J., of the Pontificia Universidad Javeriana, Bogotá, Colombia (MPUJ-ENT); Museu de Zoologia da Universidade de São Paulo, São Paulo, Brazil (MZUSP); National Museum of Natural History, Smithsonian Institution, Washington, D.C., United States (NMNH); and Reference Collection of Aquatic Macroinvertebrates of the Limnology Laboratory, Universidad Católica de Oriente, Rionegro, Antioquia, Colombia (UCO).

Dissected genitalia were stored in microvials containing glycerin, or glued to a card point together with the specimen. Morphological terminology is based on Rodrigues et al., (2014a, b). Color descriptions were made using dry specimens. All measurements are given in millimeters; lengths were measured at the midline. Antennomeres and abdominal segment numbers are expressed as Roman numerals. In the Material examined sections, a comma separates different information, a semicolon separates information of different specimens, and a slash (/) separates data of different labels; specimens, method of preservation, and deposition institutes appear inside parenthesis. 


\section{RESULTS AND DISCUSSION}

Taxonomy

Veliidae Brullé, 1836

Veliinae Brullé, 1836

\section{Genus Oiovelia Drake \& Maldonado-Capriles, 1952}

Oiovelia currently comprises 10 described species and its distribution extends from southern Mexico to Argentina (Floriano \& Rodrigues, 2016). The species are predominantly foam-inhabitants, although they can be collected at the banks of streams without foam masses. The genus was recently revised (Rodrigues et al., 2014a) and subsequently two additional species were described (Rodrigues \& Moreira, 2016a; Floriano \& Rodrigues, 2016).

\section{Oiovelia shepardi Rodrigues n. sp.} (Figs. 1, 3A-D, 3I, 5)

Description: Macropterous female: HOLOTYPE, length 4.50; maximum width (across humeral angles) 1.50 . Paratypes $(n=5)$, length 4.30-4.70 (mean $=4.42)$; maximum width 1.40-1.50 (mean $=1.42)$.

Color: Head and pronotum orange. Fore wings dark brown with whitish to yellowish maculae between cells. Antennae, greater portion of legs, pleura, ventral thorax, and abdomen blackish. Distal margins of coxae and trochanters yellowish brown (Fig. 1).

Head: Length 0.75; maximum width (across eyes) 0.73 . Declined anteriorly, covered by fine golden pubescence and long dark setae concentrated dorsally in front of eyes; dorsally with longitudinal midline impressed and a pair of oblique indentations near posterior margin. Ocular setae present. Antenniferous tubercle developed, shining. Antenna covered by golden pubescence and elongate dark setae; antennomere I more robust than II-IV, curved laterally, with lateral margins slightly diverging posteriorly; II longer and slightly more robust than III and IV; IV fusiform, slightly longer than III; length of antennomeres I -0.70 , II -0.60 , III - 0.33, IV -0.40 .

Thorax: Pronotum length at midline 0.82 ; covered by fine golden pubescence; anterior lobe with elongate dark setae concentrated laterally; anterior lobe with row of rounded punctations adjacent to anterior margin, without marks or evident pruinosity; posterior lobe covered by rounded punctations, slightly larger towards apex; humeral angles slightly elevated; posterior margin rounded. Fore wing reaching tip of abdomen, leaving only posterior portion of genital segment exposed; four closed cells; veins at basal half with elongate dark setae. Propleuron with a row of rounded punctations on epimeron. Mesopleuron with a row of rounded punctations on episternum and another of small rounded punctations on epimeron. Metapleuron with a set of silvery se- tae on epimeron. Prosternum with rounded punctations anteriorly. Meso- and metasternum each centrally with two pairs of small tubercles on intersegmental region.

Legs: Densely covered by short, appressed, golden setae and elongate dark setae, without spines. Fore tibia with small grasping comb at apex (Fig. 3l). Leg measurements as follows: foreleg, femur 0.95, tibia 0.96, tarsomeres 1-3, $0.05,0.08,0.35$; middle leg, femur 1.25 , tibia 1.36, tarsomeres $1-3,0.10,0.20,0.44$; hind leg, femur 1.45, tibia 1.80 , tarsomeres $1-3,0.08,0.25,0.46$.

Abdomen: Covered by silvery pubescence and elongate dark setae, the latter concentrated on laterotergites and lateral margins. Laterotergites slightly elevated, posterior angle of last segment rounded, not developed into spines. Abdominal sterna unmodified. Sternum II compressed laterally. First gonocoxa plate-like. Proctiger small, globose.

Macropterous male: Paratypes $(n=5)$, length 3.80-4.04 (mean = 3.87); maximum width (across humeral angles) 1.30-1.40 (mean $=1.32$ ). Similar to macropterous female in coloration and structure, except: grasping comb larger, 2.2-2.4 long. Laterotergites not elevated. Posterior margin of sternum VII concave (Fig. 1C). Posterior margin of tergum VIII with elongate dark setae (Figs. 3A-C); anterior margin excavated ventrally (Fig. 3B); posterior margin slightly concave dorsally (Fig. 3A). Proctiger without spines on dorsal surface. Paramere elongate, slightly narrowed in the middle, with rounded apex (Fig. 3D).

Distribution and habitat: This species is distributed in La Guajira and Antioquia departments of Colombia, northern South America (Fig. 5), in localities that vary between 100 to 929 meters of elevation, and probably occurs only west of the Andes. The specimens were collected in streams without accumulate foam at banks, which is the typical habitat of other Oiovelia species.

Comparative notes: The new species can be distinguished from congeners by the orange color of the head and pronotum, the absence of a V-shaped pruinose area on the posterior lobe of pronotum, the fore wing with basal maculae poorly delimited at the distal region and additional whitish to yellowish maculae between cells (Fig. 1A), and the female with a small grasping comb at the apex of the fore tibia (Fig. 3l). Oiovelia shepardi n. sp. is morphologically similar to Oiovelia cunucunumana Drake \& Maldonado-Capriles, 1952, and resembles it by also having the color of the pronotum orange, absence of a V-shaped pruinosity on the posterior lobe of the pronotum, and the paramere slightly narrowed in the middle with the apex rounded. However, in the new species the pronotum has no blackish areas on the lateral margin of the anterior lobe, the basal macula of the fore wing is poorly delimited at the distal region, the areas between cells of the fore wing have evident pruinosity and in some specimens whitish to yellowish maculae, and the female has a small grasping comb at the apex of the anterior tib- 
ia; whereas in O. cunucunumana the head is blackish with a posterior orange band, the pronotum usually has dark areas in the lateral margins of the anterior lobe, the basal macula of the fore wing is well delimited at the distal region, the areas between cells of the fore wing have at most a slight pruinosity, without additional maculae, and the female does not have a grasping comb on the apex of the fore tibia.

The genital segments of O. johnpolhemi Floriano \& Rodrigues, 2016 are also very similar to those of the new species, and in addition, the head and pronotum are orange, and there is whitish pruinosity between the cells of the fore wing. However, O. johnpolhemi has dark areas on the lateral margins of the anterior lobe of pronotum, and the head and pronotum have a striking orange color, whereas in 0 . shepardi n. sp. the dark areas are absent from the pronotum, and the head and pronotum have a softer orange color.

Discussion: Grasping comb sensu Hale (1926) and Andersen (1982) is a structure of the fore tibia of most species of Veliidae, which consists of a row of strong and small modified spines present at the apex of the segment, usually occupying half of the tibia (it may be shorter or
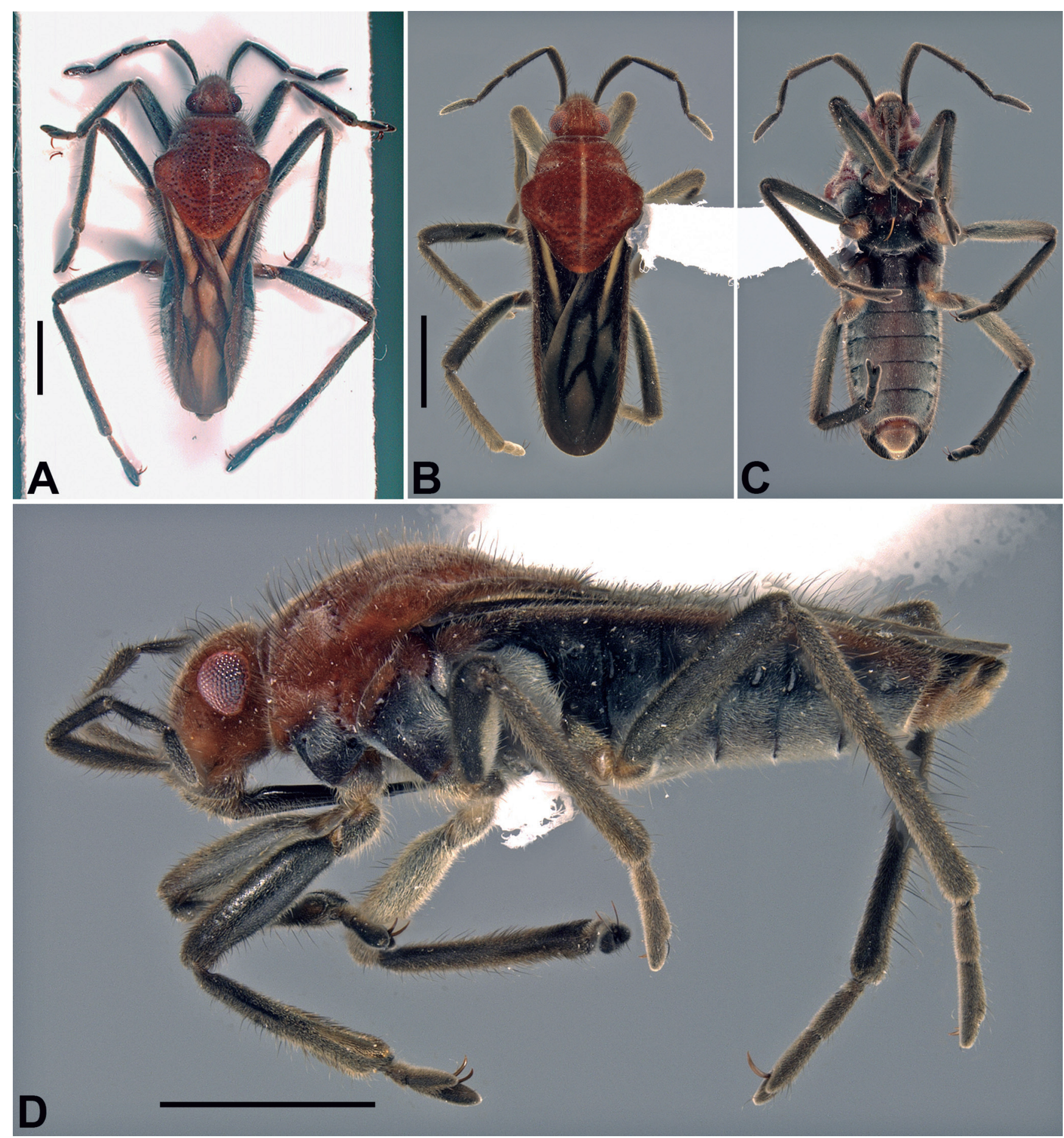

Figure 1. Oiovelia shepardi n. sp., (A) holotype, macropterous female, dorsal view (MPUJ-ENT); (B-D) paratype, macropterous male (EMEC); (B) Dorsal view, (C) ventral view, (D) lateral view. Size bar $=1 \mathrm{~mm}$. 

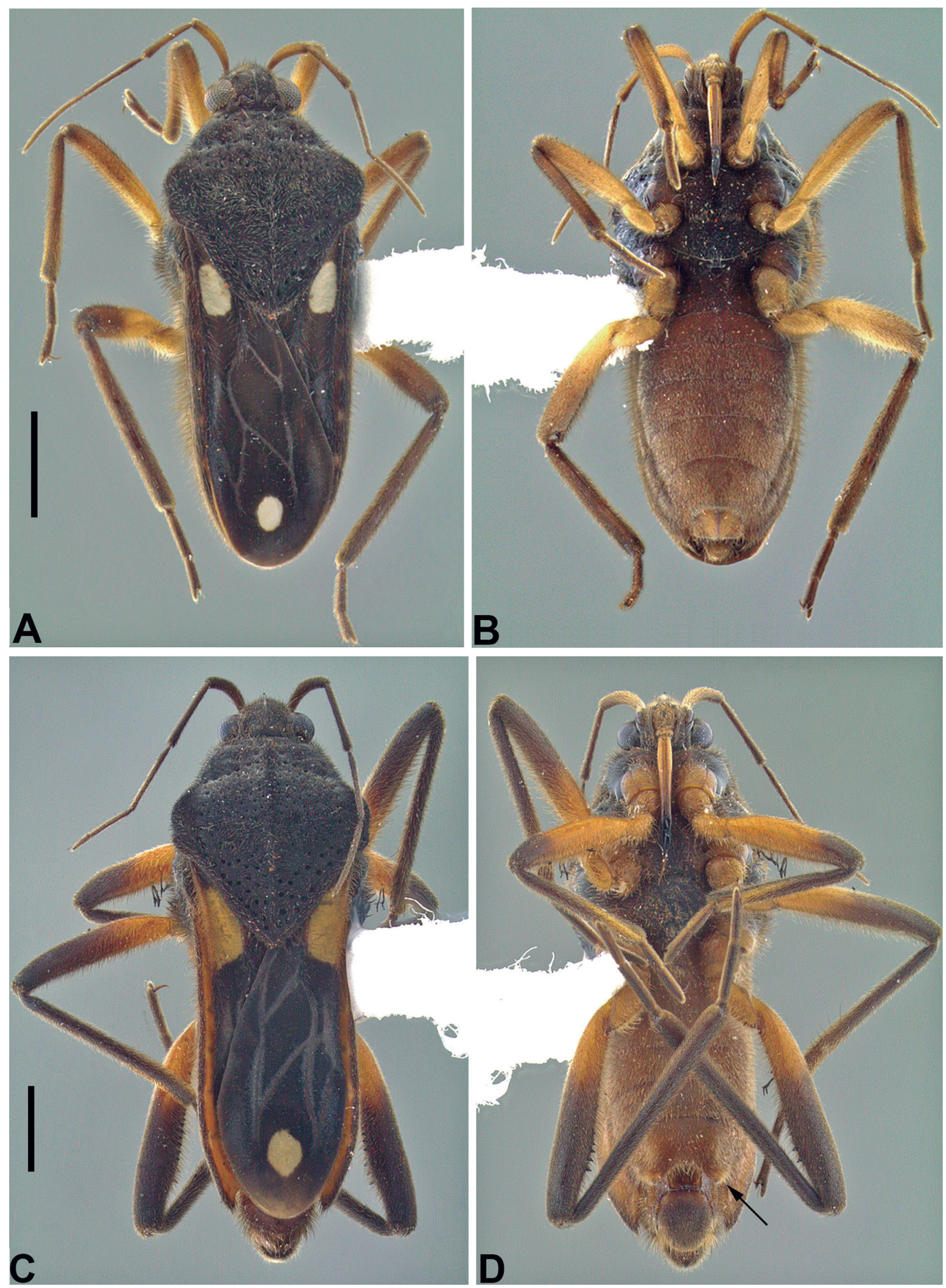

Figure 2. Paravelia spp. (A-B) Paravelia cunhai, macropterous female from Canaã dos Carajás, Brasil (MZUSP); (A) Dorsal view, (B) ventral view; (C-D) Paravelia polhemusi, macropterous male from Canaã dos Carajás, Brasil (MZUSP); (C) Dorsal view, (D) ventral view, black arrow indicates projections of abdominal tergum VII. Size bar $=1 \mathrm{~mm}$. 
longer in some species). According to Andersen (1982), this structure is a putative synapomorphy of the family, although it has been lost secondarily in some genera. This is usually present only in the male, but in some species it may also be present in the female. When a species has this structure in both sexes, it is always smaller in the female, sometimes occupying only a small portion of the apical region of the tibia. In Oiovelia, this structure was previously known to be present only in males, occupying the apical $2 / 3$ of the fore tibia (Rodrigues et al., 2014a). The presence of a grasping comb in the female of $O$. shepardi n. sp. makes this the only species of Oiovelia with such structure present in both sexes. For this reason, a female is designated as holotype.

Etymology: This species is named in honor of William D. Shepard, retired professor from the California State University, Sacramento, U.S.A., who collected the first specimen examined by the author. Currently, "Bill" Shepard is a collaborator at the collection of the Essig Museum of Entomology, Berkeley. The name is treated as a Latin noun in the genitive case.

Type material examined: All specimens macropterous, glued to a paper point. HOLOTYPE female, COLOMBIA, Antioquia, Río Nare, tributario del Embalse Punchiná, $06^{\circ} 24^{\prime} \mathrm{N}, 75^{\circ} 03^{\prime} \mathrm{W}, 07 . \mathrm{XI} .2009$, 1806, I. Cristina Gil \& E. Peláez col. (MPUJ-ENT 0063895). PARATYPES: COLOMBIA, Antioquia, Sonsón, Río La Miel en el corregimiento de San Miguel, $05^{\circ} 45^{\prime} 16.5^{\prime \prime} \mathrm{N}, 74^{\circ} 42^{\prime} 52.3^{\prime \prime} \mathrm{W}, 177 \mathrm{~m}$ a.s.l., 24.XI.2010, 2975, D.P. Gómez \& E. Peláez col. (1 male, MPUJ-ENT 0063894; 1 male, MZUSP); COLOMBIA, Antioquia, Sonsón, Río Samaná Sur, 0544'15.8060"N, $74^{\circ} 46^{\prime} 40.0623^{\prime \prime}$ W, 157 m a.s.I., 21.X.2011, 2617, I. Cristina Gil \& E. Peláez col. (1 female, MPUJ-ENT 0063893); COLOMBIA, Antioquia, Sonsón, Río La Miel en el corregimiento de San Miguel, 0545'16.5"N, 74²4'52.3"W, 177 m a.s.l., 24.IV.2014, 3261, D.P. Gómez \& E. Peláez col. (1 female, MZUSP); COLOMBIA, Antioquia, Mpio. San Carlos, 27.III.[2016], 929 m, Quebrada Canaveral, N06 12.19', W7456.74', WDS-A-2039, William D. Shepard leg., L-1946 (1 male, EMEC); COLOMBIA, La Guajira, Fonseca, Río Ranchería, debajo de los 100 m, $10^{\circ} 56^{\prime} 07.9130^{\prime \prime} \mathrm{N}, 72^{\circ} 50^{\prime} 04.0623^{\prime \prime} \mathrm{W}, 01 . \mathrm{V} .2011$, 2481, F. Álvarez col. (1 male, MPUJ-ENT 0063892; 1 male, UCO; 1 female, MZUSP; 2 females, UCO).

\section{Genus Paravelia Breddin, 1898}

Paravelia is currently comprised of 51 described species and its distribution extends from Mexico to Argentina (Rodrigues et al., 2014b; Aristizábal-García et al., 2015; Rodrigues \& Moreira, 2016b, c; Polhemus et al., 2019). The species can be collected in a great variety of environments such as emergent vegetation of streams and lakes, temporary pools, in the tanks of bromeliads, and subterranean waters in caves. The taxonomy of the genus has been examined in the recent years, with articles aimed at redescribing and photographing known species, as well as describing new species (e.g., Polhemus, 2014; Rodrigues et al., 2014b; Rodrigues \& Moreira, 2016b, c; Polhemus et al., 2019). In general, in the field it is common to collect only one or a few specimens of Paravelia species. Two recently described species from Brazil are examples of the type series composed only by the holotype: P. cunhai and P. polhemusi.

\section{Paravelia cunhai Rodrigues \& Moreira, 2016 (Figs. 2A-B, 5)}

Paravelia cunhai Rodrigues \& Moreira, 2016b: 184-187 (original description).

Description: Macropterous female $(n=2)$ : Length 4.50-4.80, maximum width (across the humeral angles) 1.80-1.95. Similar to male in color and morphology (Figs. 2A-B) except: Fore tibia with small grasping comb, $0.12 \mathrm{~mm}$ long. Hind femur with 7-9 small spines on mesal margin of distal half. Laterotergites slightly elevated. Lateral margins of abdominal segments III-V with whitish pruinose areas below insertion region of lateral abdominal muscles (viewed using a posterior illumination). Posterior corner of last laterotergite rounded to slightly acuminate, not forming a spine. Venter of abdomen without black denticles. Superior portion of first gonocoxa with some black denticles.

Distribution: Brazil, Pará: Vitória do Xingu (Rodrigues \& Moreira, 2016b), Canaã dos Carajás (present study) (Fig. 5).

Discussion: The pattern of maculae on the fore wings of the female is similar to that of the holotype. This species was described based on a macropterous male collected inside a cave, without incidence of light, in the State of Pará, northern Brazil (Rodrigues \& Moreira, 2016b). The two females examined here also were collected inside a cave in the State of Pará.

Material examined: All specimens macropterous, glued to a paper point, and deposited at MZUSP. Brazil, Pará: Brasil, Pará, Canaã dos Carajás, Serra da Bocaina, caverna, 620096 mE, 9306129 mN, SAD 69, 05-15.Mar.2012, Pellegati et al., col., GEM 1471, Carste 2523 (1 female); same data, except Carste 2594 ( 1 female).

\section{Paravelia polhemusi Rodrigues, Moreira, Nieser, Chen \& Melo, 2014 (Figs. 2C-D, 3E-H, 3J, 5)}

Paravelia polhemusi Rodrigues, Moreira, Nieser, Chen \& Melo in Rodrigues et al., 2014b: 19-21 (original description).

Description: Macropterous male $(n=10)$ : length 6.30-6.55 (mean $=6.36$ ), maximum width (across humeral angles) $2.10-2.30$ (mean $=2.21)$. Similar to female 


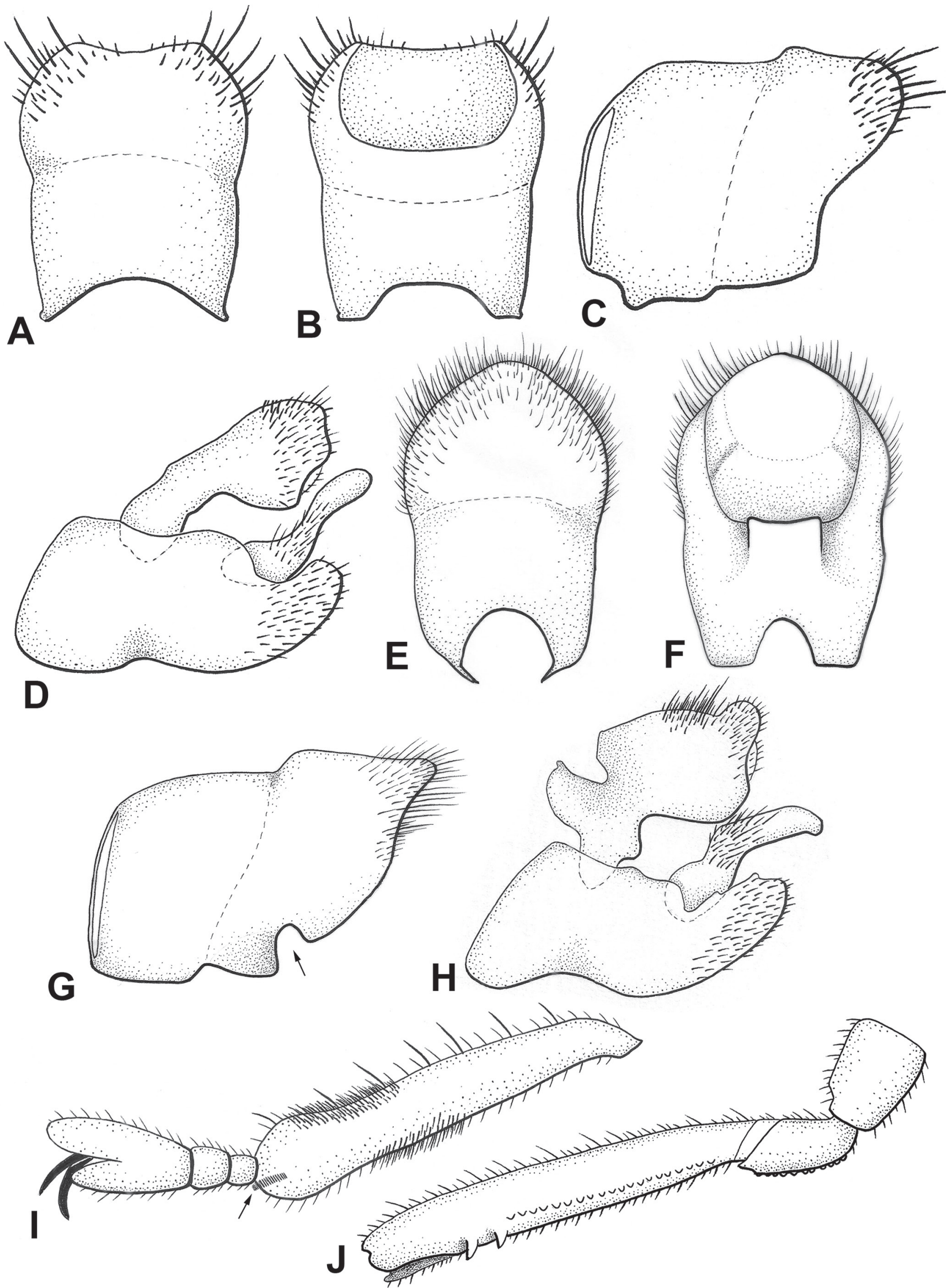

Figure 3. (A-D, I) Oiovelia shepardi n. sp., (A-C) abdominal tergum VIII of male; (A) Dorsal view, (B) ventral view, (C) lateral view; (D) Male genital capsule, lateral view; (I) tibia and tarsomeres of the female fore leg, arrow indicates grasping comb; (E-H, J) Paravelia polhemusi, (E-G) abdominal tergum VIII of male; (E) Dorsal view, (F) ventral view, (G) lateral view, arrow indicates excavation; (H) Male genital capsule, lateral view; (J) coxa, trochanter and femur of the hind leg. 
in color and morphology (Figs. 2C-D), except: grasping comb of fore tibia 1.25-1.30 mm long, occupying almost entire length of segment. Hind trochanter with irregular row of small spines on mesal margin. Hind femur with a small and irregular row of small spines at basal region, followed by a row of 20 spines on mesal margin and two more prominent and somewhat offset spines apically (Fig. 3J). Abdominal sternum VII with a pair of distinct and slightly divergent projections on posterior margin (Fig. 2D). Abdominal tergum VIII without black denticles; posterior region covered by brown setae dorso-laterally; posterior margin rounded to slightly acuminate dorsally (Fig. 3E); ventro-laterally slightly depressed, with an angular gibbosity on each side of meson at posterior margin (Figs. 3F-G). Proctiger with elongate brown setae on posterior region, flattened at base in frontal view; triangular keel at middle of dorsal surface. Paramere elongate, slightly curved, with a small notch on dorsal surface near base; tuft of elongate brown setae on basal half; distal margin rounded to slightly truncate (Fig. $3 \mathrm{H}$ ).

Distribution: Brazil, Mato Grosso: Nova Xavantina (Rodrigues et al., 2014b); Pará: Canaã dos Carajás (present study) (Fig. 5).

Discussion: This species was described based only on the macropterous female holotype (Rodrigues et al., 2014b). The holotype was collected in a stream in the municipality of Nova Xavantina, central-western Brazil. In the present study, this species is recorded from the State of Pará, at Canaã dos Carajás, northern Brazil. The material examined here was collected inside a cave located in a transition area between Amazonian Forest vegetation and "Canga" (small areas of open vegetation in outcrops of iron ore). Thus, P. polhemusi also has troglophilic habits. To date, four species of Paravelia have been recorded in subterranean waters of caves in northern and northeastern Brazil: P. cunhai, P. digitata Rodrigues \& Moreira, 2016, P. nieseri Moreira \& Barbosa, 2012 and P. splendoris (Drake \& Harris, 1933) (Rodrigues \& Moreira, 2016c). As these species can also be found outside of caves, they are considered facultative cave organisms. Rodrigues et al. (2014b) differentiated P. polhemusi from P. basalis (Spinola, 1837) based on body length, general color, and the basal yellowish macula on the fore wing. After the discovery of the male of $P$. polhemusi it is possible to report that it has a pair of projections on the abdominal sternum VII, a character also present in the male of $P$. basalis. The males of these two species are easily separated by the characters of the terminalia. In $P$. polhemusi the tergum VIII is excavated on the posterior half in lateral view, and the proctiger has a keel on the posterior half of the dorsal surface, whereas in $P$. basalis the excavation of the tergum VIII and the keel on the dorsal surface of the proctiger are absent (see Rodrigues \& Moreira, 2016c: p. 656 , figs. 33,35 ).

In the original description, the authors included an illustration of the abdomen in lateral view of the holotype to show the shape of the segment VII of laterotergites (see Rodrigues et al., 2014b: 21, fig. 12). However, the au- thors subsequently discovered that figures $12 \mathrm{D}$ and $12 \mathrm{E}$ were reversed, and figure 12D is actually P. polhemusi and figure $12 \mathrm{E}$ is $P$. ornata Rodrigues, Moreira, Nieser, Chen \& Melo, 2014b.

Material examined: All specimens macropterous, glued to a paper point, and deposited at MZUSP. BRAZIL, Pará: Brasil, Pará, Canaã dos Carajás, 613818 mE, 9300640 mN, SAD 69, 28.Jan-05.fev.2013, Pellegatti et al., col., GEM 1436, Carste 2592 (1 female); same data, except Carste 2596 (1 female); Brasil, Pará, Canaã dos Carajás, gruta, 571854 mE, 9292404 mN, SAD 69, 01-02.VIII.2012, Andrade et al., col., S11D-06N, Carste 2629 (1 female); same data, except $598513 \mathrm{mE}, 9300797 \mathrm{mN}$, SAD 69, 17-24.X.2008, GEM 1578 CL, Carste 2890 (1 female); Brasil, Pará, FLONA Carajás, gruta, Ualace, 28.set-03.Out.2007, Andrade et al., col., N1-143, Carste 2892 (3 males, 2 females); Brasil, Pará, FLONA Carajás, gruta, $596113 \mathrm{mE}$, 9325034 mN, SAD 69, 07-12.X.2008, Andrade et al., col., N5510 CL, Carste 2889 (2 males, 3 females); same data, except $596301 \mathrm{mE}, 9325116 \mathrm{mN}$, SAD 69, N5511 CL, Carste 2894 (4 males, 1 female); same data, except Tio Edy, 28.Set-03.Out.2007, N1-72, Carste 2893 (3 males); same data, except Carste 2897 (1 male); Brasil, Pará, Carajás, gruta, 599908 mE, 9301572 mN, SAD 69, 17-24.X.2008, Andrade et al., col., GEM 1564 CL, Carste 2904 (2 females).

\section{Genus Steinovelia Polhemus \& Polhemus, 1993}

Steinovelia currently comprises five described species and its distribution extends from southeastern Canada to Argentina (Polhemus \& Polhemus, 1993). The species can be collected among emergent vegetation in lentic environments and are occasionally collected in light traps. Although the genus is not very diverse, it is in need of a taxonomic revision to determine if all species are valid.

\section{Steinovelia vinnula (Drake, 1951) (Figs. 4A-C, 5)}

Velia vinnula Drake, 1951: 375-376 (original description). Paravelia vinnula: Polhemus, 1976: 513 (new comb.).

Steinovelia vinnula: Polhemus \& Polhemus, 1993: 397 (new comb.); Nieser \& Melo, 1997: 100 (identification key).

Description: Micropterous female $(n=1)$. Body length 4.40, maximum width (across the humeral angles) 1.05. Similar to macropterous specimens (Fig. 4A-B), except: pronotum narrower. Fore wings reduced, reaching anterior margin of abdominal mediotergite II (Fig. 4A). Abdominal mediotergites II-V with a longitudinal dark brown stripe medially; VI almost entirely dark brown; VII with lateral margins dark brown.

Distribution: Brazil, Amazonas: Iranduba (present study); Maranhão: Santa Helena (present study); São Paulo: Ribeirão Preto (Drake, 1951) (Fig. 5). 
Discussion: Steinovelia vinnula can be easily distinguished from other species of the genus based on the broad hind femur with large spines centrally on the mesal margin (Figs. 4A-C). Despite this fact, the short description and lack of drawings in Drake (1951) might have led to confusion between this species and S. virgata (White, 1879) (Fig. 4D) by subsequent authors. Possible synonymy between S. vinnula and S. virgata was suggested by Nieser \& Melo (1997), but not confirmed because types were not available to them. In their identification

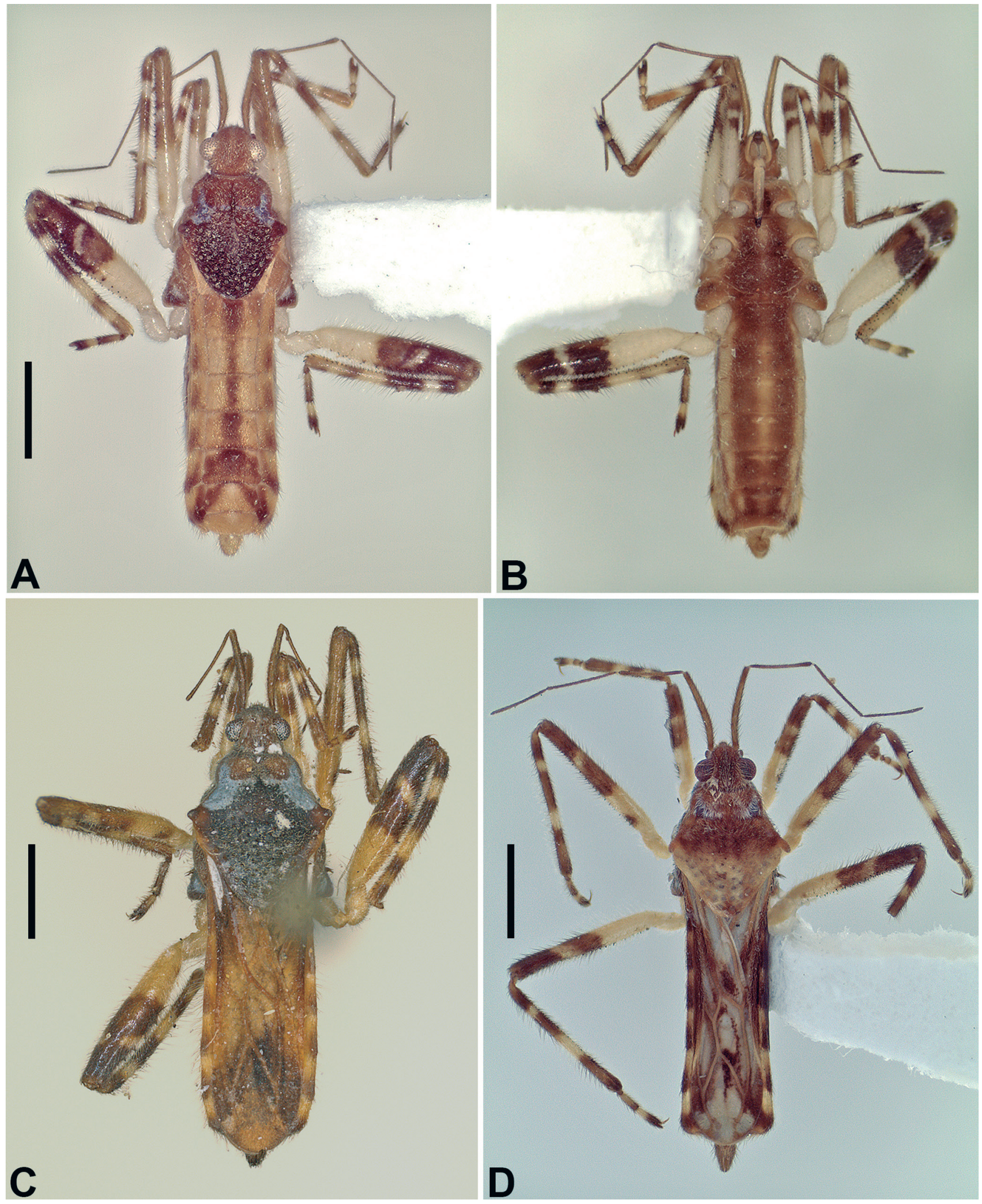

Figure 4. Steinovelia spp. (A-C) Steinovelia vinnula, (A-B) micropterous female from Iranduba, Brasil (MZUSP), (A) dorsal view, (B) ventral view; (C) Macropterous female from Santa Helena, Brasil (INPA), dorsal view; (D) Steinovelia virgata, macropterous female from Rio Grande do Sul, Brasil, dorsal view (MZUSP). Size bar = $1 \mathrm{~mm}$. 


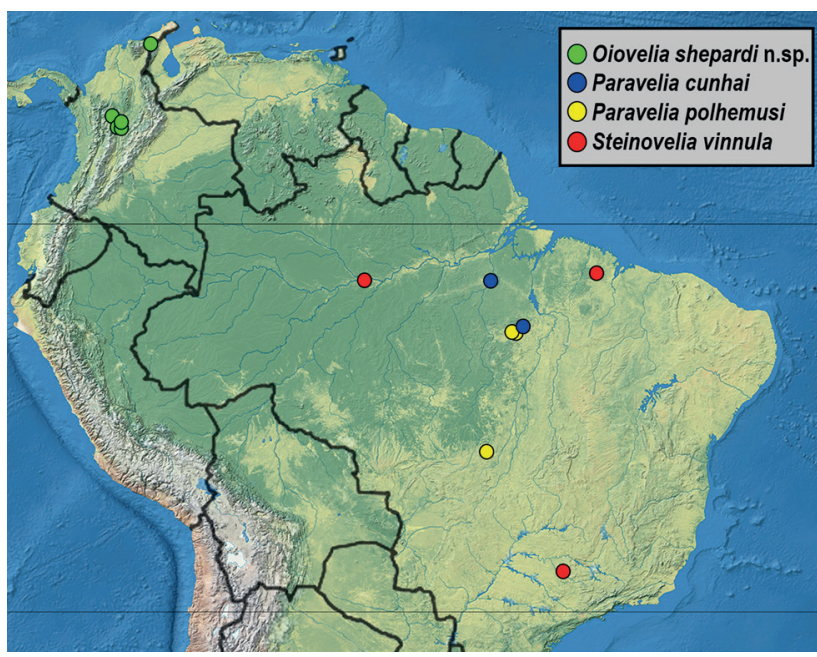

Figure 5. Distribution records for the species treated in the present study.

key, only a minor difference in the antennal proportions was given to distinguish the two species. After examining the type specimens of both for the present study, we are certain of the validity of the two as distinct species. The main morphological difference between S. vinnula and S. virgata is the thickness of the hind femur and the size of its spines of the mesal margin (compare Figs. 4C-D).

Type material examined: HOLOTYPE (macropterous female, pinned, NMNH): Ribeiro Preto [= Ribeirão Preto], São Paulo Brazil, January 26, 1939, E.J. Hambleton/ CJ Drake Coll. 1956/ USNM ENT 00871020.

Additional material examined: BRAZIL, Amazonas, Iranduba, várzea do Rio Solimões, Lago da Marchantaria, 27.Vl.2011, H. Rodrigues col. (1 micropterous female, glued to a paper point, MZUSP); BRAZIL, Maranhão, Santa Helena, Alto Turi, 18.VIII.1965, Cerq. \& Ed. col. (1 macropterous female, pinned, INPA).

\section{ACKNOWLEDGMENTS}

We are grateful to Marcelo Duarte, Ana Vasquez, Thalita Fonseca (MZUSP), Thomas J. Henry (NMNH), Márcio Oliveira and Thiago Mahlmann (INPA) for providing access to their institutions collections; Dimitri Forero (MPUJ-ENT) for making available the entomological collection for deposit of the type series of the new species; William Shepard (EMEC) for facilitating study of part of the material examined; and Cheryl Barr (EMEC) for the kind language review of the manuscript. Financial support was provided by the São Paulo Research Support Foundation (FAPESP: 2013/16654-0 and 2015/18338-3). Felipe. F.F. Moreira (Instituto Oswaldo Cruz, Rio de Janeiro) and an anonymous referee provided useful comments improving the final version of this paper.

\section{REFERENCES}

Andersen, N.M. 1982. The semiaquatic bug (Hemiptera, Gerromorpha): phylogeny, adaptations, biogeography and classification. Entomonograph, 3: 1-455.

Aristizábal-García, H.; Floriano, C.F.B.; Moreira, F.F.F. \& Bispo, P.C. 2015. New species and notes on Microveliinae from northern South America (Hemiptera: Heteroptera: Veliidae). Zootaxa, 3980(4): 591-596.

Drake, C.J. 1951. New water striders from the Americas (Hemiptera: Veliidae). Revista de Entomologia, Rio de Janeiro, 22: 371-378.

Floriano, C.F.B. \& Rodrigues, H.D.D. 2016. A new species of Oiovelia (Heteroptera: Gerromorpha: Veliidae) from Mesoamerica, with an identification key to the genus. Zootaxa, 4144(4): 584-592.

Hale, H.M. 1926. Studies in Australian aquatic Hemiptera. VII. Families Naeogeidae, Mesoveliidae, Veliidae. Records of the South Australian Museum, 3: 195-217.

Moreira, F.F.F. 2015. The semiaquatic Gerromorphans. In: Panizzi, A.R. \& Grazia, J. (Eds.). True bugs (Heteroptera) of the Neotropics. Springer / Sociedade Brasileira de Entomologia. p. 113-156.

Nieser, N. \& Melo, A.L. 1997. Os Heterópteros Aquáticos de Minas Gerais: Guia Introdutório com Chave de Identificação para as Espécies de Nepomorpha e Gerromorpha. Belo Horizonte, Editora UFMG. 180p.

Polhemus, D.A. 2014. Two new Peruvian species of Paravelia (Heteroptera: Veliidae) from water-filled bamboo internodes, and distributional notes for other Paravelia species. Tijdschrift Voor Entomologie, 157: 151-162.

Polhemus, D.A.; Molano, F.; Morales, I.; Moreira, F.F.F. \& Floriano, C.F.B. 2019. Altavelia, a new genus of Neotropical Veliinae (Heteroptera: Gerromorpha: Veliidae), with a key to species and descriptions of four new species from Colombia. Zootaxa, 4585(2): 295-314.

Polhemus, J.T. 1976. A reconsideration of the status of the genus Paravelia Breddin, with other notes and a check list of species (Veliidae: Heteroptera). Journal of the Kansas Entomological Society, 49: 509-513.

Polhemus, J.T. \& Polhemus, D.A. 1993. Two new genera for New World Veliinae (Heteroptera: Veliidae). Journal of the New York Entomological Society, 101: 391-398.

Rodrigues, H.D.D. \& Moreira, F.F.F. 2016a. A new species and new records of Oiovelia (Heteroptera: Gerromorpha: Veliidae) from Brazil. Zootaxa, 4078(1): 153-160

Rodrigues, H.D.D. \& Moreira, F.F.F. 2016b. A new species, new synonymy, and notes on Paravelia Breddin (Hemiptera: Heteroptera: Veliidae). Papéis Avulsos de Zoologia, 56(17): 183-188.

Rodrigues, H.D.D. \& Moreira, F.F.F. 2016c. Four new species of Paravelia (Hemiptera: Heteroptera:Veliidae) from Brazil, with notes on previously described species. Canadian Entomologist, 148: 642-667.

Rodrigues, H.D.D.; Melo, A.L. \& Ferreira-Keppler, R.L. 2014a. Taxonomic revision of the Neotropical genus Oiovelia (Hemiptera: Heteroptera: Veliidae). Acta Entomologica Musei Nationalis Pragae, 54(1): 65-98.

Rodrigues, H.D.D.; Moreira, F.F.F.; Nieser, N.; Chen, P.P.; Melo, A.L.; Dias-Silva, K. \& Giehl, N.F.S. 2014b. The genus Paravelia Breddin, 1898 (Hemiptera: Heteroptera: Veliidae) in Brazil, with descriptions of eight new species. Zootaxa, 3784: 1-47 